Jurnal Epidemiologi Kesehatan Komunitas

5 (2), 2020, 96-103

\title{
JEKK
}

\section{Deteksi Dini Faktor Risiko Penyakit Jantung dan Pembuluh Darah, Hubungan Antara Obesitas, Aktivitas Fisik dan Kolesterol Total di Kecamatan Kertapati, Kota Palembang}

\author{
Achmad Ridwanmo*, Mariatul Fadillah*, dan Tri Hari Irfani* \\ *Bagian Ilmu Kesehatan Masyarakat Ilmu Kedokteran Komunitas Fakultas Kedokteran Universitas Sriwijaya, \\ Palembang
}

\begin{abstract}
Background: Cardiovascular disease is the first cause of death in Indonesia. The prevalence of stroke based on diagnosis rose from 7 (2013) to 10.9 per mil (2018), The prevalence of cardiovascular disease is 1.5 per mil. Research on the detection of risk factors for cardiovascular disease using a cardiovascular risk score according to WHO and the Jakarta Score has never been conducted in Palembang. The purpose of this study is to conduct early detection of risk factors to predict cardiovascular disease in the next 10 years, and find out the relationship between obesity, physical activity to reduce cholesterol.
\end{abstract}

Methods: This research was conducted using an observational analytic study with cross sectional design and multistage sampling method. Samples in this study were 126 people from 3 village in Kertapati district in Palembang City.

Result: The research showed that high level risk to cardiovascular disease in 10 years by using WHO non laboratory, laboratory and Jakarta Score was 4,8\%, 6,7\%, 61,9\% respectively. Whereas, the moderate risk was $20 \%, 26,2 \%$ and $25,4 \%$. There was no association between obesity and total cholesterol $(\mathrm{p}=0.682)$, but there was an association between physical activity and total cholesterol $(\mathrm{p}=0.030$, OR 3,1). Moreover, there was a total cholesterol's mean difference between none/mild, moderate, and severe physical activity that is $36,6 \mathrm{mg} / \mathrm{dl}$ ( $\mathrm{t}$ test, $\mathrm{p}$-value: $0,005)$.

Conclusion: Lack of physical activity could be the one of cholesterol risk factor. Therefore, doing the physical activity could prevent the cardiovascular disease.

Keywords: Early detection; prediction; cardiovascular; cholesterol; physical activity

*Penulis korespondensi, achmad.ridwanmo@yahoo.com 


\section{Pendahuluan}

Penyakit kardiovaskuler (termasuk penyakit jantung koroner dan stroke) adalah penyakit tidak menular terbanyak di dunia. Penyakit kardiovaskuler diperkirakan menyebabkan 17,8 juta kematian di tahun 2017, dan lebih dari dua pertiganya terjadi di negara berpenghasilan rendah dan menegah. ${ }^{1}$ Di Indonesia penyakit tidak menular termasuk kardiovaskuler menjadi beban ganda penyakit, yaitu di satu pihak masih adanya penyakit infeksi yang harus ditangani dan di lain pihak penyakit tidak menular seperti penyakit jantung, hipertensi, ginjal dan stroke semakin meningkat. ${ }^{2}$ Kecenderungan ini dipengaruhi juga dengan banyaknya perubahan seperti perubahan sikap hidup, modernisasi, dan globalisasi. ${ }^{3}$ Proporsi angka kematian penyakit tidak menular meningkat dari $41,7 \%$ pada tahun 1995 menjadi 59,5\% pada tahun 2007. ${ }^{4}$

Prevalensi beberapa faktor risiko penyakit kardiovaskuler berdasarkan hasil Riskesdas tahun 2007 antara lain berat badan lebih dan obesitas 19,1\%, obesitas sentral 18,8\%, diabetes mellitus di daerah perkotaan 5,7\%, sering (satu kali atau lebih setiap hari) makan makanan asin $24,5 \%$, sering makan makanan berlemak 12,8\%, kurang sayur dan buah $93,6 \%$, kurang aktivitas fisik 48,2\%, gangguan mental emosional $11,6 \%$, perokok setiap hari 23,7\%, dan konsumsi alkohol 12 bulan terakhir 4,6\%. Penyakit Jantung Koroner (PJK) merupakan penyakit dengan prevalensi cukup tinggi di masyarakat umum maupun masyarakat pekerja, serta berperan bagi kematian sebesar $36 \%$, kesakitan dan tidak mampu kerja. ${ }^{1}$

Faktor risiko penyakit kardiovaskuler terdiri dari faktor risiko yang dapat dicegah dan tidak dapat dicegah. Faktor risiko yang dapat dicegah terdiri dari faktor risiko yang secara jelas berpengaruh untuk terjadinya PJK. Faktor risiko yang dapat dicegah tersebut meliputi hipertensi, merokok, dan diabetes mellitus. Salah satu upaya penting dalam pencegahan terjadinya penyakit kardiovaskuler yang dapat dilakukan adalah dengan mengidentifikasi faktor risiko penyakit kardiovaskuler dari setiap individu dengan berbagai model antara lain Framing Heart Study, WHO/ISH risk prediction chart dan skor kardiovaskuler Jakarta.

Data mengenai skor faktor risiko kardiovaskuler di Kecamatan Kertapati, Kota Palembang saat ini masih belum ditemukan laporannya. Penelitian ini bertujuan untuk mengetahui profil risiko penyakit kardiovaskuler dalam 10 tahun mendatang berdasarkan skor risiko penyakit kardiovaskuler model WHO non laboratorium dan laboratorum serta model Jakarta. Profil risiko penyakit kardiovaskuler ini dapat digunakan dalam rangka pengendalian penyakit jantung dan pembuluh darah di masyarakat.

\section{Metode}

Penelitian ini merupakan penelitian observasional dengan menggunakan desain studi cross sectional. Besar sampel adalah 126 orang diambil dari penduduk di tiga kelurahan menggunakan multi stage sampling yaitu di Kecamatan Kertapati. Pengumpulan data primer dilakukan melalui wawancara menggunakan kuesioner dan lembar observasi. Kriteria inklusi sampel yaitu bersedia menjadi responden, berdomisili di lokasi penelitian, sedangkan kriteria ekslusi dalam penelitian ini adalah tidak didiagnosis salah satu penyakit jantung dan pembuluh darah. Profil faktor risiko akan dinilai berdasarkan tiga model yaitu model WHO non laboratorium, model WHO laboratorium dan model Jakarta. Model WHO non laboratorium terdiri dari lima variabel, yaitu: usia, jenis kelamin, tekanan darah sistolik, status merokok, dan Indeks Massa Tubuh (IMT). Sedangkan model WHO laboratorium terdiri satu variabel, yaitu: total kolesterol. Model Jakarta menggunakan tujuh variabel, yaitu: usia, jenis kelamin, tekanan darah sistolik atau diastolik, Index Massa Tubuh (IMT), status merokok, riwayat diabetes mellitus dan aktivitas fisik. Analisis data dilakukan secara univariat dan bivariat. Analisis univariat dilakukan dengan tabel distribusi frekuensi pada masing-masing variabel. Sedangkan analisis bivariat dilakukan dengan menggunakan uji t independen untuk mengetahui adanya perbedaan rerata antara variabel obesitas dan aktivitas fisik terhadap kadar kolesterol total serta uji chi square untuk mengetahui adanya hubungan antara variabel 
obesitas dan aktivitas fisik terhadap kadar kolesterol total.

\section{Hasil}

Berdasarkan skor risiko kardiovaskuler model WHO non laboratorium didapatkan presentase tingkat risiko penyakit jantung dan pembuluh darah pada responden yaitu risiko rendah $(74,6 \%)$, risiko sedang $(20 \%)$, dan risiko tinggi $(4,8 \%)$. Distribusi frekuensi responden berdasarkan model WHO non laboratorium adalah sebagai berikut: rerata usia $53,18 \pm 8,92$ tahun, rerata tekanan darah 139,25 $+22,44 \mathrm{mmHg}$, dan rerata IMT $23,73 \pm 5$. Proporsi kelompok usia terbesar adalah pada responden yang berusia 55-59 tahun (20,6\%), berjenis kelamin perempuan $(60,3 \%)$, bukan perokok $(66,6 \%)$, dan memiliki tekanan darah $>140-159 \mathrm{mmHg}(53,2 \%)$. Hasil analisis secara lengkap disajikan pada tabel 1.

Tabel 1. Karakteristik Subjek Penelitian dan Berbagai Faktor Risiko Menurut Skor Risiko Kardiovaskuler WHO (Skor WHO/ISH) Non Laboratorium

\begin{tabular}{|c|c|c|c|}
\hline Variabel & Kategori & n (\%) & Rerata (Mean) \\
\hline $\begin{array}{l}\text { Tingkat risiko penyakit jantung } \\
\text { pembuluh darah }\end{array}$ & $\begin{array}{l}\text { Tinggi } \\
\text { Sedang } \\
\text { Rendah }\end{array}$ & $\begin{array}{c}6(4,8 \%) \\
20(20,0 \%) \\
74(74,6 \%)\end{array}$ & - \\
\hline Jenis kelamin & $\begin{array}{c}\text { Laki-laki } \\
\text { Perempuan }\end{array}$ & $\begin{array}{l}50(39,7 \%) \\
76(60,3 \%)\end{array}$ & - \\
\hline Perokok & $\begin{array}{c}\text { Tidak } \\
\text { Merokok }\end{array}$ & $\begin{array}{l}85(66,6 \%) \\
41(32,5 \%)\end{array}$ & - \\
\hline Usia & $\begin{array}{l}\text { 40-44 tahun } \\
\text { 44-49 tahun } \\
\text { 50-54 tahun } \\
\text { 55-59 tahun } \\
\text { 60-64 tahun } \\
\text { 65-69 tahun } \\
\text { 70-74 tahun }\end{array}$ & $\begin{array}{c}25(19,8 \%) \\
22(17,5 \%) \\
16(12,7 \%) \\
26(20,6 \%) \\
22(17,550 \\
9(7,1 \%) \\
6(4,8 \%)\end{array}$ & $53,18 \pm 8,92$ \\
\hline TDS (dalam mmHG) & $\begin{array}{c}<120 \\
120-139 \\
140-159 \\
160-179 \\
\geq 180\end{array}$ & $\begin{array}{c}10(7,9 \%) \\
48(38,1 \%) \\
53(42,1 \%) \\
11(8,3 \%) \\
4(3,2 \%)\end{array}$ & $139,25 \pm 20,44$ \\
\hline IMT & $\begin{array}{l}<20 \mathrm{~kg} / \mathrm{m} 2 \\
20-24 \mathrm{~kg} / \mathrm{m} 2 \\
25-29 \mathrm{~kg} / \mathrm{m} 2 \\
30-34 \mathrm{~kg} / \mathrm{m} 2 \\
\geq 35 \mathrm{~kg} / \mathrm{m} 2\end{array}$ & $\begin{array}{c}28(22.2 \%) \\
61(48,4 \%) \\
12(9,5 \%) \\
24(19,0 \%) \\
1(8,0 \%)\end{array}$ & $23,73 \pm 5,00$ \\
\hline
\end{tabular}


Berdasarkan skor risiko kardiovaskuler WHO laboratorium didapatkan presentase tingkat risiko penyakit jantung dan pembuluh darah yaitu risiko rendah $(65,1 \%)$, risiko sedang (20\%), dan risiko tinggi $(6,7 \%)$. Sedangkan, berdasarkan distribusi frekuensi model WHO laboratorium dapat diketahui bahwa kadar kolesterol total responden terbanyak adalah di level $4(154,44) \mathrm{mg} / \mathrm{dl}$ dengan presentase sebesar 34,1\%. Hasil selengkapnya disajikan pada tabel 2 .

Tabel 2. Tingkat Risiko Penyakit Kardiovaskuler Menurut Skor Risiko Kardiovaskuler WHO (Skor WHO/ISH) Laboratorium

\begin{tabular}{lcc}
\hline \multicolumn{1}{c}{ Variabel } & Kategori & n (\%) \\
\hline Tingkat risiko penyakit Jantung & Tinggi & $11(6,7 \%)$ \\
pembuluh darah & Sedang & $33(26,2 \%)$ \\
& Rendah & $82(65,1 \%)$
\end{tabular}

\begin{tabular}{lcc}
\hline Kolesterol total & $4(154,44) \mathrm{mg} / \mathrm{dl}$ & $43(34.1 \%)$ \\
& $5(193,05) \mathrm{mg} / \mathrm{dl}$ & $32(25,4 \%)$ \\
& $6(231,66) \mathrm{mg} / \mathrm{dl}$ & $14(11,1 \%)$ \\
$7(270,27) \mathrm{mg} / \mathrm{dl}$ & $27(29,4 \%)$ \\
& $8(308,788) \mathrm{mg} / \mathrm{dl}$ & $0(0,0 \%)$
\end{tabular}

Berdasarkan model risiko kardiovaskuler model Jakarta didapatkan presentase tingkat risiko penyakit jantung dan pembuluh darah yaitu risiko tinggi $(61,9 \%)$, risiko sedang $(22,2$ $\%)$, dan risiko rendah $(15,9 \%)$. Distribusi frekuensi responden berdasarkan model Jakarta yaitu responden paling banyak berusia 55-59 tahun $(20,6 \%)$, berjenis kelamin perempuan
(60.3\%), memiliki tekanan darah sistolik sebesar 140-159 mmHg (41,3\%), tidak merokok $(51,6 \%)$, tidak memiliki riwayat DM $(81,7 \%)$, memiliki IMT 13,79-25,99 kg/m2 $(73,8 \%)$, dan aktivitas fisik mingguan berat $(47,6 \%)$. Hasil selengkapnya disajikan pada tabel 3 .

Tabel 3. Karakteristik Subjek Penelitian dan Berbagai Faktor Risiko Menurut Skor Risiko Kardiovaskuler Jakarta (Skor Jakarta)

\begin{tabular}{lllc}
\hline \multicolumn{1}{c}{ Variabel } & \multicolumn{1}{c}{ Kategori } & n (\%) & Rerata (Mean) \\
\hline Tingkat risiko penyakit Jantung & Tinggi & $70(61,9 \%)$ & - \\
pembuluh darah & Sedang & $28(22,2 \%)$ & \\
& Rendah & $20(15,9 \%)$ & \\
\hline Usia (dalam tahun) & & & \\
& $40-44$ tahun & $25(19,8 \%)$ & $53,68 \pm 8,916$ \\
& $45-49$ tahun & $22(17,5 \%)$ & \\
& $50-54$ tahun & $16(12,7 \%)$ & \\
& $55-59$ tahun & $26(20,6 \%)$ & \\
& $60-64$ tahun & $22(17,5 \%)$ & \\
& $>64$ tahun & $15(1,9 \%)$ &
\end{tabular}




\begin{tabular}{|c|c|c|c|}
\hline Variabel & Kategori & n (\%) & Rerata (Mean) \\
\hline Jenis kelamin & $\begin{array}{l}\text { Laki-laki } \\
\text { Perempuan }\end{array}$ & $\begin{array}{l}50(39,7 \%) \\
76(60,3 \%)\end{array}$ & - \\
\hline Tekanan darah sistolik (mmHg) & $\begin{array}{l}<130 \\
130-139 \\
140-159 \\
160-179 \\
180>\end{array}$ & $\begin{array}{c}34(27,0 \%) \\
25(19,8 \%) \\
52(41,3 \% \\
11(8,7 \%) \\
4(3,2 \%)\end{array}$ & $139,25 \pm 20,44$ \\
\hline Perokok & $\begin{array}{l}\text { Tidak } \\
\text { Pernah merokok } \\
\text { Masih merokok }\end{array}$ & $\begin{array}{l}65(51,6 \%) \\
20(15,0 \%) \\
41(32,5 \%)\end{array}$ & - \\
\hline Riwayat DM & $\begin{array}{l}\text { Ya } \\
\text { Tidak }\end{array}$ & $\begin{array}{c}33(18,4 \%) \\
103(81,7 \%)\end{array}$ & - \\
\hline Indeks Masa Tubuh $(\mathrm{kg} / \mathrm{m} 2)$ & $\begin{array}{l}13,79-25,99 \\
26,00-29,99 \\
30.00-34,58\end{array}$ & $\begin{array}{c}93(73,8 \%) \\
8(6,3 \%) \\
25(19,8 \%)\end{array}$ & $23,73 \pm 5,00$ \\
\hline Aktifitas fisik mingguan & $\begin{array}{l}\text { Tidak ada } \\
\text { Ringan } \\
\text { Sedang } \\
\text { Berat }\end{array}$ & $\begin{array}{l}18(14.3 \%) \\
26(20,6 \%) \\
22(17,5 \%) \\
60(47.6 \%)\end{array}$ & - \\
\hline
\end{tabular}

Hubungan antara Obesitas, Aktivitas Fisik dengan Kolesterol Total

Tabel 4. Perbedaan Rerata Kolesterol pada Obesitas dan Aktifitas Fisik

\begin{tabular}{llcccc}
\hline \multicolumn{1}{c}{ Variabel } & \multicolumn{1}{c}{ Kategori } & n & Rerata \pm SD & Beda Rerata & p-value \\
& & & & & \\
\hline Obesitas & Ya & 28 & $184,25 \pm 34$ & $6,76(11-24)$ & 0,456 \\
& Tidak & 98 & $177,5 \pm 43,9$ & & \\
\hline Aktivitas fisik & Tidak ada+rendah & 53 & $202,84 \pm 34,4$ & $36,6(36,6-7,1)$ & 0,005 \\
& Sedang+berat & 73 & $166,2 \pm 41,4$ & & \\
\hline
\end{tabular}

Pada tabel 4 dapat diketahui bahwa rerata kolesterol pada responden yang obesitas lebih tinggi $(184,2 \mathrm{mg} / \mathrm{dl})$ jika dibandingkan dengan rerata kolesterol total pada responden yang tidak obesitas $(177,5 \mathrm{mg} / \mathrm{dl})$, dengan perbedaan rerata sebesar $6,76 \mathrm{mg} / \mathrm{dl}$. Pada uji t didapatkan nilai p-value sebesar 0,456 $(>0,05)$, yang berarti tidak terdapat perbedaan rerata kadar kolesterol total antara responden yang obesitas dengan yang tidak obesitas. Rerata kolesterol pada responden yang memiliki aktivitas ringan atau rendah lebih tinggi $(202,8$ $\mathrm{mg} / \mathrm{dl}$ ) jika dibandingkan dengan rerata kadar kolesterol total responden yang memiliki aktivitas sedang atau berat $(166,2 \mathrm{mg} / \mathrm{dl})$, dengan perbedaan rerata sebesar $36,6 \mathrm{mg} / \mathrm{dl}$. Pada uji $t$ independent diketahui nilai .p-value sebesar $0,005(<0,05)$, yang berarti terdapat 
perbedaan bermakna rerata kadar kolesterol total antara responden yang tidak beraktivitas fisik atau beraktivitas fisik ringan dan responden yang memiliki aktivitas fisik sedang dan berat.

Tabel 5. Perbedaan Proporsi Kolesterol pada Obesitas dan Aktivitas Fisik

\begin{tabular}{|c|c|c|c|c|c|c|c|}
\hline \multirow{3}{*}{ Variabel } & \multicolumn{4}{|c|}{ Kolesterol Total } & \multirow{3}{*}{ Total } & \multirow{3}{*}{ p-value } & \multirow{3}{*}{$\mathbf{O R}$} \\
\hline & \multicolumn{2}{|c|}{ Tinggi } & \multicolumn{2}{|c|}{ Normal } & & & \\
\hline & $\mathbf{n}$ & $\%$ & $\mathbf{n}$ & $\%$ & & & \\
\hline \multicolumn{8}{|l|}{ Obesitas } \\
\hline$-\mathrm{Ya}$ & 9 & 32.1 & 19 & 67.9 & 28 & 0,682 & - \\
\hline -Tidak & 32 & 32.7 & 66 & 67.5 & 98 & & \\
\hline \multicolumn{8}{|l|}{ Aktifitas fisik } \\
\hline -Tidak+rendah & 22 & 50,0 & 22 & 50,05 & 44 & 0,007 & 3,1 \\
\hline -Sedang+berat & 20 & 24,4 & 62 & 75,60 & 82 & & $(1,52-5,74)$ \\
\hline
\end{tabular}

Berdasarkan tabel 6 dapat diketahui bahwa proporsi responden dengan kolesterol total tinggi pada responden yang obesitas adalah sebesar 32,1\%, sedikit lebih rendah jika dibandingkan dengan responden yang tidak obesitas yaitu sebesar $32,7 \%$. Pada uji chisquare diketahui bahwa tidak terdapat hubungan antara obesitas dengan kolesterol $(\mathrm{p}=0,687)$. Sedangkan proporsi responden dengan total kolesterol tinggi yang tidak beraktivitas fisik dan beraktivitas fisik rendah

\section{Pembahasan}

Berdasarkan hasil penelitian dapat diketahui bahwa proporsi responden dengan risiko tinggi penyakit kardiovaskuler menurut kriteria model Jakarta lebih besar yaitu 61,9 \% (78 orang), dibandingkan dengan proporsi responden dengan risiko tinggi penyakit kardiovaskuler berdasarkan skor model WHO yaitu sebesar 4,8\% (model WHO non laboratorium) dan $6,7 \%$ (model WHO laboratorium). Proporsi responden dengan risiko tinggi yang lebih besar pada model Jakarta dan berbeda dengan proporsi pada model WHO laboratorium dan non laboratorium, dapat disebabkan karena adanya perbedaan dalam pengkategorian variabel umur. Pada skor model WHO umur dikategorikan dari usia 40 sampai dengan 74 tahun, sedangkan pada model Jakarta umur dikategorikan dari usia 25 sampai dengan 64 adalah sebesar 50\%, lebih tinggi jika dibandingkan dengan responden yang memiliki aktivitas fisik sedang dan berat yaitu sebesar 24,4\%. Pada uji chi-square diketahui bahwa terdapat hubungan antara obesitas dan kolesterol $(p=0,007)$, dengan nilai OR sebesar 3,1 , yang berarti bahwa risiko total kolesterol tinggi 3,1 kali lebih besar pada responden yang tidak beraktivitas fisik atau beraktivitas fisik ringan dibandingkan dengan responden yang memiliki aktivitas fisik sedang dan berat.

tahun. Selain itu, tidak terdapat variabel aktivitas fisik pada skor model WHO, sedangkan pada skor model Jakarta terdapat variabel aktivitas fisik.

Hasil penelitian menunjukkan tidak terdapat beda rata-rata kadar kolesterol total antara responden yang obesitas dengan yang tidak obesitas. Demikian, juga tidak terdapat beda proporsi antara responden dengan kadar kolesterol total tinggi pada responden yang obesitas dengan yang tidak obesitas. Hal tersebut tidak sesuai dengan teori yang mengatakan bahwa penyebab utama hiperlipidemia (peningkatan kolesterol dan/ atau trigliserida serum di atas batas normal) adalah obesitas, konsumsi alkohol yang berlebihan, diabetes meliitus, hipotiroid dan sindrom nefrotik. ${ }^{10}$ Tidak adanya hubungan antara obesitas dan kadar kolesterol total dapat terjadi karena terbatasnya sampel serta adanya 
pengaruh variabel lain seperti aktivitas fisik dan diet yang dilakukan oleh responden.

Hasil penelitian juga menunjukkan adanya beda rata-rata kadar kolesterol total antara responden yang tidak beraktivitas fisik dan beraktivitas fisik rendah dengan responden yang beraktivitas fisik sedang dan berat. Demiakian, juga terdapat perbedaan rerata kadar kolesterol total antara responden yang tidak beraktivitas dan beraktivitas rendah dengan responden yang beraktivitas fisik sedang dan tinggi. Hal tersebut sesuai dengan teori yang mengatakan bahwa kurangnya aktivitas berperan dalam timbulnya dislipidemia. Kurangnya aktivitas fisik menyebabkan ketidakseimbangan nutrisi dalam tubuh dimana lemak tetap tertimbun. Selain itu, hasil penelitian ini sejalan dengan penelitian mengenai hubungan aktivitas fisik dengan kadar kolesterol total, kolesterol low-density lipoprotein, dan kolesterol high-density lipoprotein pada masyarakat Jatinangor yang menyatakan adanya hubungan antara aktivitas fisik dengan kadar kolesterol total. ${ }^{22}$

\section{Kesimpulan}

Hasil penelitian menunjukkan bahwa proporsi responden yang memiliki tingkat risiko tinggi mengalami penyakit kardiovaskuler pada 10 tahun mendatang dengan menggunakan kriteria WHO non-laboratorium, laboratorium dan kriteria skor Jakarta berturut turut adalah 4,8 $\%, 6,7 \%$, dan $61,9 \%$. Sedangkan, proporsi responden yang memiliki tingkat risiko sedang mengalami penyakit kardiovaskuler pada 10 tahun mendatang dengan menggunakan kriteria WHO non-laboratorium, laboratorium dan kriteria skor Jakarta berturut turut adalah $20 \%$, $26,2 \%$ dan $25,4 \%$. Selain itu, juga diketahui bahwa tidak terdapat hubungan antara obsesitas dengan kadar kolesterol total melalui uji $\mathrm{t}$ $(\mathrm{p}=0,456)$ dan uji chi-square $(\mathrm{p}=0.682)$. Terdapat hubungan antara aktivitas fisik dan kadar kolesterol total $(\mathrm{p}=0.030 ; \mathrm{OR}=3,1)$. Selain itu, diketahui juga bahwa terdapat beda rata-rata kadar kolesterol total antara responden yang tidak beraktivitas fisik, beraktivitas fisik ringan, sedang, dan berat sebesar 35,6 mg/dl ( $\mathrm{p}=0,005)$.

\section{Referensi}

1. The WHO CVD Risk Chart Working Group. 2019. WHO cardiovascular disease risk charts: revised models to estimate risk in 21 global regions., The Lancet Global Health, 7 (10).

2. Supriyono, Mamat. 2008. Faktor-faktor risiko yang berpengaruh terhadap kejadian penyakit jantung koroner pada kelompok usia < 45 tahun (tesis). Universitas Diponegoro, Semarang. (Diakses tanggal 12 Juli 2019).

3. Kementrian Kesehatan RI. 2010. Deteksi dini faktor risiko penyakit jantung dan pembuluh darah edisi I, Direktorat Jendral PP dan PL Direktorat Pengendalian Penyakit Tidak Menular, Jakarta.

4. Cooney, M.T., Dudina, A., Agostiona, R., Graham, I.M. Cardiovascular riskestimation systems in primary prevention. http;/abajournal.org, diakses 24 Juni 2019.

5. Departemen Kesehatan RI. 2007. Pedoman pengendalian penyakit jantung dan pembuluh darah, Direktorat Jendral PP dan PL Direktorat Pengendalian Penyakit Tidak Menular Jakarta.

6. World Health Organization. 2001. WHO world health organization report 2000, Genewa: WHO.

7. Departemen Kesehatan RI. 2003. Survei kesehatan nasional 2001: laporan studi mortalitas 2001: pola penyakit penyebab kematian di Indonesia, Badan Penelitian dan Pengembangan Kesehatan, Jakarta; 76 hlm.

8. Anis. 2006. Waspada ancaman penyakit tidak menular, solusi pencegahan dari aspek perilaku \& lingkungan, PT Elex Media Komputindo, Jakarta, 53-65.

9. Departemen Kesehatan RI. 2006. Pedoman teknis penemuan dan tatalaksana penyakit hipertensi, Direktorat Jendral PP dan PL 
Direktorat Pengendalian Penyakit Tidak Menular, Jakarta.

10. Price.S.A, Wilson, L.M., 2005. Patofiologi konsep klinis proses-proses penyakit, Penerbit Buku Kedokteran, edisi 6, Volume 1, EGC: Jakarta.

11. Vinay Kumar, Ramzi S. Cotran, dan Stanley L. Robbins. 2007. Buku ajar patologi robbins edisi 7. Penerbit Buku Kedokteran EGC: Jakarta.

12. American Heart Association (AHA) Scientific Position. 2007. Risk factors and coronary heart disease, AHA Scientific Position, November 24, 1-3.

13. McWhinney, Ian R. 2009. Textbook of family medicine. Oxford University Press, Inc. New York.

14. Sylvia A. Price, Lorraine M. Wilson. 2004. Patofisiologi - konsep klinis proses-proses penyakit, Penerbit Buku Kedokteran EGC: Jakarta, 528-556.

15. Jian L., Christopher S., Richard P.D. 2005. Joint distribution of non-HDL and LDL cholesterol and coronary heart disease risk prediction among individuals with and without diabetes, Diabetes Care, Vol.28, USA, August 8, 2005, 28: 1916-1921.

16. Departemen Kesehatan, Republik Indonesia. 2008. Riset kesehatan dasar
(Riskesdas 2007), Laporan Nasional 2007, Badan Penelitian dan Pengembangan Kesehatan: Jakarta.

17. Depkes RI. 2007. Pedoman surveilans epidemiologi penyakit jantung dan pembuluh darah, Dit. Pengendalian PTM, Ditjen P2PL: Jakarta.

18. Ridwan A, Sakinah, A.N.A., dan Sari, G.P, .2019. Surveilans faktor risiko penyakit kardiovaskuler metode skor kardiovaskuler Jakarta, di Puskesmas Sabokingking dan Puskesmas 1 Ulu Kota.

19. Lameshow,S., Hosmer, D.W., Klar, J and Lwanga, S.K, 1990. Adecuacy sample size in health studies, WHO.

20. Sugiharto A, Suharyo H, Sakundarno A, Shofa C. Faktor-Faktor risiko hipertensi grade II pada masyarakat (studi kasus di Kabupaten Karanganyar). Bagian Penyakit Dalam Rumah Sakit Dr. Kariadi/FK Undip Semarang. Available in http://eprints.undip.ac.id/5265/1/Aris_Sugi harto.pdf.

21. Zuhroiyyah S.F., Hadyana S., Sunaryo B.S. 2017. Hubungan aktivitas fisik dengan kadar kolesterol total, kolesterol low-density lipoprotein, dan kolesterol high-density lipoprotein pada masyarakat Jatinangor. Jurnal Sistem Kesehatan. 2(3): 116-122. 